\title{
Prevalence of equine herpesvirus types 2 and 5 in horse populations by using type-specific PCR assays
}

\author{
Ann Nordengrahn a*, Malik Merza ${ }^{\mathrm{a}}$, Carlos Ros ${ }^{\mathrm{b}}$, Arne LindHOLM ${ }^{\mathrm{c}}$, \\ Vilmos PÁLFid ${ }^{d}$, Duncan HANNANT ${ }^{e}$, Sándor BELÁK ${ }^{b}$
}

\author{
asvanova Biotech AB, Uppsala Science Park, Glunten, S-751 83 Uppsala, Sweden \\ ${ }^{b}$ Department of Virology, National Veterinary Institute, Uppsala, Sweden \\ ${ }^{c}$ Department of Medicine and Surgery, University of Agricultural Sciences, Uppsala, Sweden \\ ${ }^{\mathrm{d} D e p a r t m e n t}$ of Virology, National Veterinary Institute, Budapest, Hungary \\ ${ }^{\mathrm{e}}$ Centre for Preventive Medicine, Animal Health Trust, Newmarket, United Kingdom
}

(Received 1 October 2001; accepted 4 January 2002)

\begin{abstract}
Equine herpesvirus types 2 and 5 (EHV-2 and EHV-5) have a rather unclear pathogenicity and distribution within the equid population. In order to gain more information on the prevalence of these two viruses, type-specific PCR assays were developed to detect viral DNA in nasal specimens and in peripheral blood leukocytes (PBLs) of adult horses and foals from various regions of Europe, i.e. Sweden, Hungary and the United Kingdom. In adult horses, the prevalence of EHV-2 in PBLs was up to $68 \%$ in Sweden and $71 \%$ in the United Kingdom. EHV-2 DNA was detected in the PBLs from all the foals tested in all countries and most $(93 \%)$ of the nasal specimens also yielded positive results. The prevalence of EHV-5 DNA in the PBLs of foals in Hungary was 15 and 24\% in adult horses in the United Kingdom. This observation was among the very few reports of the presence of EHV-5 in horses. In summary, the specific PCR assays revealed important data on the occurrence and distribution of EHV-2 and EHV-5 in large horse populations. The findings indicated that infection with EHV-5 occurred later than EHV-2 in foals. This study may contribute to a better understanding of the etiological role of these gammaherpesviruses in equine diseases.
\end{abstract}

equine infections / Gammaherpesvirinae / EHV-2 / EHV-5 / PCR

Résumé - Prévalence des herpesvirus équins types 2 et 5 dans les populations de chevaux par l'utilisation de PCR spécifiques du type. Les herpesvirus équins de types 2 et 5 (EHV-2 et EHV-5) ont un pouvoir pathogène et une distribution mal connus parmi la population des équidés. Afin de recueillir plus d'informations sur la prévalence de ces deux virus, des tests PCR spécifiques du type ont été développés afin de détecter l'ADN viral dans les prélèvements nasaux et dans les leucocytes du

*Correspondence and reprints

Tel.: (46) 186740 00; fax: (46) 186746 67; e-mail: ann.nordengrahn@svanova.com 
sang périphérique (LSP) de chevaux adultes et de poulains provenant de diverses régions d'Europe : Suède, Hongrie et Royaume Uni. Chez les chevaux adultes, la prévalence de EHV-2 dans les LSP atteignait $68 \%$ en Suède et $71 \%$ au Royaume-Uni. L'ADN de EHV-2 a été détecté dans les LSP de tous les poulains testés, et la plupart (93\%) des prélèvements nasaux étaient également positifs. La prévalence de l'ADN de EHV-5 dans les LSP des poulains en Hongrie était de $15 \%$ et de $24 \%$ chez les chevaux adultes au Royaume-Uni. Cette observation fait partie des très rares signalements de la présence de EHV-5 chez les chevaux. En résumé, les tests PCR spécifiques ont révélé des données importantes sur la présence et la distribution de EHV-2 et EHV-5 dans d'importantes populations de chevaux. Les résultats ont montré que l'infection par le EHV-5 se produisait plus tard que celle par le EHV-2 chez le poulain. Cette étude apporte une meilleure compréhension du rôle étiologique de ces herpesvirus gamma dans les maladies équines.

\section{infections équines / Gammaherpesvirinae / EHV-2 / EHV-5 / PCR}

\section{INTRODUCTION}

Equine herpesvirus types 2 and 5 (EHV-2 and EHV-5) were recently classified within the Gammaherpesvirinae subfamily [19]. EHV-2 is widely spread in horse populations and it has been isolated from healthy animals as well as from horses with different clinical signs. EHV-2 infection occurs most frequently in young foals, and the most common symptoms are keratoconjunctivitis, respiratory disease with pneumonia and pharyngitis, fever, enlarged lymph nodes, inappetence/anorexia, general malaise, and poor performance $[1,8,9,21,22]$. EHV-2 is also able to establish persistent infections [6]. Various observations indicate that EHV-2 should not be neglected as a pathogen in equids. There are convincing results indicating that EHV-2 has a role as a predisposing factor for Rhodococcus equi invasion in the respiratory tract. The "trigger mechanism" of this virus in initiating the bacterial invasion has been demonstrated in experiments using passive and active immunisation against EHV-2 to protect against $R$. equi infections [3, 4, 14, 16].

Studies on the genomic heterogeneity of EHV-2 have revealed the existence of another gammaherpesvirus in the horse, termed EHV-5 [8]. The initial isolates of EHV-5 were obtained from the culturing of samples from the buffy coat/nasal cavity of Australian horses and a horse imported to Australia from the United Kingdom suffer- ing from upper respiratory tract disease [8]. Recently the occurrence of EHV-5 has also been reported in Switzerland, Germany and New Zealand [7, 11, 12].

To carry out comparative studies on the closely related EHV-2 and EHV-5, the choice of method is important. By the use of immunofluorescence [7], it was shown that as many as $93 \%$ of tested equids in German zoos had antibodies to EHV-2 and EHV-5. The authors suggested that due to a strong serological cross-reactivity this test does not discriminate between the two viruses. In contrast, detection of EHV-2 DNA by the polymerase chain reaction (PCR) was positive in 16 of 55 tested animals, while EHV-5 DNA was detected only in one [7].

In order to investigate the presence of EHV-2 and EHV-5 in various horse populations, we developed a specific PCR assay for each virus. Primers were selected from various regions of the glycoprotein $\mathrm{H}(\mathrm{gH})$ gene for specific and discriminative amplification of EHV-2 and EHV-5, respectively. Whole blood and nasal swab specimens of horses, from sample banks in Sweden, Hungary and the United Kingdom were analysed with the two specific PCR assays. The direct detection of specific EHV-2 and EHV-5 DNA sequences is of major importance to obtain more detailed information about the prevalence of these two viruses on large geographic areas and to estimate their possible pathological role in the horse populations. 


\section{MATERIALS AND METHODS}

\subsection{Viruses and cells}

A Hungarian isolate of EHV-2, strain KT-5797 [14] and an Australian isolate of EHV-5, strain 2-141 [8] were propagated in the rabbit kidney cell line (RK-13) as described elsewhere [15].

\subsection{Virus purification}

EHV-2 and EHV-5 was purified as previously described [15].

\subsection{Clinical samples}

To estimate the occurrence and prevalence of EHV-2 and EHV-5, specimens from existing sample banks of our institutes were used in this study.

In Sweden peripheral blood leukocytes (PBLs) were collected from a total of 81 Standard bred trotters. The animals, originating from 2 integrated studs/racing stables were aged one year or older. The stables were chosen to represent groups of animals with annual respiratory problems associated with EHV-2 and $R$. equi, occurring regularly in the spring and summer (stable I) and a group without these disease problems (stable II). From Stable I, samples from 38 adult horses and also 33 foals were tested. The foals were aged from 5 to 8 months. In Stable II, samples from 43 adult horses were chosen. These specimens were collected over a period of 2 years, one sample from each horse. Foals were also sampled once, but all at one time.

From both stables all the adult horses and foals were tested for EHV-2 DNA while 40 of the adult horses (20 from each stable) and 10 of the foals were also tested for the presence of EHV-5 DNA.

In Hungary, PBLs and nasal swabs from 27 Arabian Thoroughbred foals from a stable with annual occurrence of respiratory disease due to EHV-2/R.equi infection were used. The foals were sampled at the age of $2,4,6,8,13,18$ and 23 weeks and all the samples were tested for both EHV-2 and EHV-5 DNA.

In the United Kingdom a total of 21 horses (Welsh mountain cross-breeds) aged 3 years or older, belonging to the Animal Health Trust, were sampled over a period of 9 years, one sample from each horse. In addition, 3 foals produced in the resident herd were sampled 4 times at the ages between 5 and 41 weeks. PBLs were tested for EHV-2 and EHV-5 DNA.

\subsection{Separation of peripheral blood lymphocytes (PBLs) and preparation of DNA from PBLs and nasal specimens}

PBL cells were separated from the EDTA blood samples by using the FicollPaque separation method (Pharmacia \& Upjohn, Uppsala, Sweden). The cells were kept in liquid nitrogen until use. Nasal specimens were collected from the nasal cavity with cotton swabs. The swabs were kept in tubes with PBS until use.

DNA was prepared by phenol/chloroform extraction [18]. The DNA concentration and purity was measured with a spectrophotometer (GeneQuant, Pharmacia LKB Biochrom, Cambridge, UK) and amounts of 0.4 to $0.5 \mu \mathrm{g}$ of total DNA were used in the PCR assay. Purified EHV-2 and EHV-5 DNA were used as positive controls and water was used as the negative control.

\subsection{Polymerase chain reaction (PCR)}

For EHV-2 DNA detection, a seminested PCR [2] was developed to amplify a 424 and 354 nucleotide fragment of the $\mathrm{gH}$ gene, respectively (Tab. I). EHV-5 DNA was detected by a single PCR [2], amplifying a 344-bp region of the $\mathrm{gH}$ gene of this virus (Tab. I). 
Table I. Specific primer sequences used for PCR amplification of EHV-2 and EHV-5.

\begin{tabular}{|c|c|c|c|c|}
\hline $\begin{array}{l}\text { Primer } \\
\text { designation }\end{array}$ & Primer sequence $5^{\prime}-3^{\prime}$ & $\begin{array}{c}\text { Target } \\
\text { specificity }\end{array}$ & $\begin{array}{c}\text { Target } \\
\text { length (bp) }\end{array}$ & $\begin{array}{l}\text { Genome } \\
\text { position }\end{array}$ \\
\hline gHEF $\quad F$ & ATGCTCTCTGACAAGAATCACTAC & $\mathrm{EHV}-2 \mathrm{gH}$ & 424 & 46 \\
\hline gHEB $\quad \mathrm{R}$ & TGTTGTAGACAATGGGAATCTG & & & 448 \\
\hline \multicolumn{5}{|c|}{ semi nested PCR ${ }^{\mathrm{a}}$} \\
\hline gHEB2 R & CGAGACAAACATCTTTTTCTCT & & 354 & 378 \\
\hline EHV-5/1 F & TAACCTCCGCGACACGTTTTCA & EHV-5 gH & 344 & 39 \\
\hline EHV-5/2 R & TAGACATCACCGCAGAAACCACAA & & & 359 \\
\hline
\end{tabular}

F: forward; R: reverse.

${ }^{\mathrm{a}}$ In the semi nested PCR, gHEF and gHEB2 primers were used.

\subsubsection{Conditions of amplification}

The EHV-2 first run of amplification and the EHV-5 single PCR were performed in $50 \mu \mathrm{L}$ volumes of reaction mixtures containing $5 \mu \mathrm{L}$ sample DNA $(0.4$ to $0.5 \mu \mathrm{g})$, $0.1 \mathrm{mM}$ (each) deoxynucleotide, $15 \mathrm{pmol}$ of each primer, $2.5 \mathrm{mM} \mathrm{MgCl}_{2}, 50 \mathrm{mM}$ $\mathrm{KCl}, 10 \mathrm{mM}$ Tris- $\mathrm{HCl}$ (pH 9.0) and $1 \mathrm{U}$ of Taq Gold DNA polymerase (Perkin-Elmer Cetus, Norwalk, CT, USA). Two droplets of mineral oil were added to the reaction mixtures to prevent evaporation.

For the EHV-2 semi-nested PCR assays, $2 \mu \mathrm{L}$ of the PCR products from the first run of amplifications were transferred to new reaction tubes, containing fresh reaction mixtures and a pair of semi-nested primers (one is internal, the other is the same as in the first run), as shown in Table I.

To prevent false positives, PCR mixtures, DNA preparations and PCR products were manipulated in separate laboratories. Microcentrifuge tube holders and openers, as well as a special pipetting procedure were used as described by Belák and BallagiPordány [5].

All the amplification reactions were carried out in a Peltier DNA engine (MJ Research, Inc. Waltham, MA, USA). The EHV-2 and EHV-5 reaction mixtures were subjected to $94{ }^{\circ} \mathrm{C}$ for 9 min to activate the polymerase, and subsequently 35 cycles with the following profile $94{ }^{\circ} \mathrm{C}$ for $1 \mathrm{~min}$ for denaturation, $55^{\circ} \mathrm{C}$ for $1 \mathrm{~min}$ for annealing and $72{ }^{\circ} \mathrm{C}$ for $1 \mathrm{~min}$ for extension. To improve the specificity, the annealing temperature of the first five cycles was $5^{\circ} \mathrm{C}$ higher. To visualise the yield, $5 \mu \mathrm{L}$ amounts of the PCR products were run on $2 \%$ agarose gels at $200 \mathrm{~V}$ for $20 \mathrm{~min}$. The gels were stained with ethidium bromide and visualised under UV-light.

\subsubsection{Primers}

In order to obtain specific PCR assays, a set of primers was selected from the gene encoding the glycoprotein $\mathrm{H}$ of the EHV-2 strain 86/67 [20] using the Oligo 4.0 program (National Biosciences Inc., Plymouth, MN, USA). By using primers, both EHV-2 and EHV-5 DNA were amplified (not shown here). The EHV-2 and EHV-5 PCR products were sequenced and from this data type specific EHV-2 and EHV-5 primers were selected (the specific primers are shown in Tab. I).

\subsubsection{Specificity and sensitivity of the PCR assays}

In order to check the specificity of the EHV-2 PCR, the primers were tested with DNA preparations of purified EHV types 1, 3,4 and 5 and with different isolates of 
EHV-2 originating from Sweden, Hungary, Australia and the USA (ATCC - VR 701). In the same way, the EHV-5 primers were tested with DNA preparations of EHV-1, 2, 3 and 4. The equine endothelial lung cell (EEL) and the RK-13 cell lines were tested as negative controls.

The sensitivity of the PCR systems was checked by using serial 10-fold dilutions of purified EHV-2 and EHV-5 DNA. The amount of $1 \mu \mathrm{g}$ viral DNA was calculated to be equivalent to approximately $5 \times 10^{9}$ virus copies.

\section{RESULTS}

\subsection{Specificity and sensitivity of the specific PCR assays}

The EHV-2 and EHV-5 specific PCR assays amplified the respective viruses. None of the heterologous viruses was amplified with the EHV-2 or EHV-5 primers. When testing serial dilutions of EHV-2 and EHV-5 DNA from the gradient purified virus, calculations showed that the EHV-2 PCR detected as few as 1-5, while the EHV-5 PCR detected 10 to 50 virus copies (data not shown).

\subsection{Detection of EHV-2 DNA by PCR}

In Sweden, EHV-2 DNA was detected from PBLs in $68 \%$ (26 out of 38 ) of the animals from stable I and 56\% (24 out of 43) from stable II (Tabs. II and III). All 33 foals from stable I were positive to EHV-2.

In Hungary, the detection of EHV-2 in PBLs showed a big increase of positive foals at 6 weeks of age and at the age of 8 weeks, all 27 foals were positive (see Fig. 1). EHV-2 DNA was detected in the nasal swabs in 25 of the 27 foals (93\%) with a peak at the age of 6 weeks (data not shown). In the United Kingdom 15 of the 21 (71\%) horses were positive to EHV-2. In the PBLs of the 3 tested foals EHV-2 was detected at the age of 12 to 16 weeks.

\subsection{Detection of EHV-5 DNA by PCR}

None of the PBLs of the 40 adult horses or the 10 foals from Sweden were positive to EHV-5 (Tab. II). In contrast, EHV-5 DNA was detected in the PBLs in four of the $27(15 \%)$ Hungarian foals, at the age of 13 to 23 weeks (see Fig. 1). In the nasal swabs EHV-5 DNA was detected in 2 of the 4 foals at the same age as the detection in the PBLs i.e. at 18 weeks (data not shown).

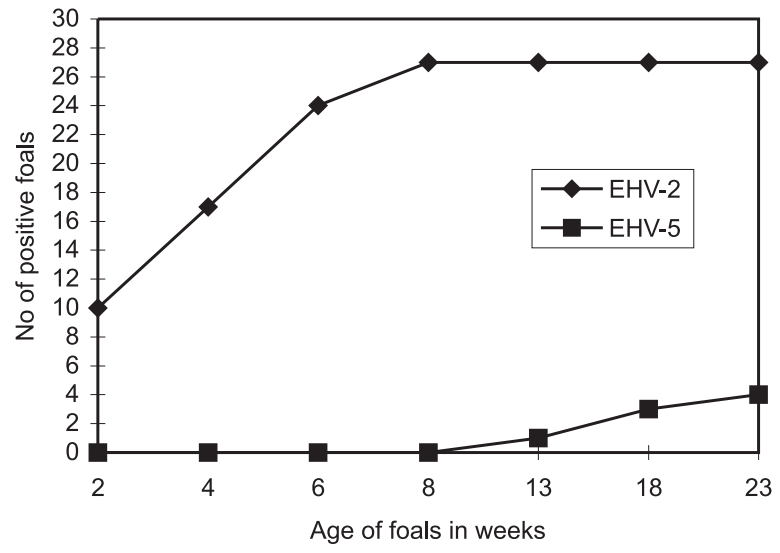

Figure 1. Time of EHV-2 and EHV-5 infections in Arabian Thoroughbred foals. No. of positive horses at age 2 to 23 weeks tested by PCR. 
A. Nordengrahn et al.

Table II. Detection of EHV-2 and EHV-5 DNA in 81 Standard bred trotters in Sweden.

\begin{tabular}{|c|c|c|c|c|}
\hline \multirow[b]{2}{*}{ Horse no. } & \multicolumn{2}{|c|}{ Stable I } & \multicolumn{2}{|c|}{ Stable II } \\
\hline & $\begin{array}{c}\text { EHV-2 } \\
\text { PCR }\end{array}$ & $\begin{array}{c}\text { EHV-5 } \\
\text { PCR }\end{array}$ & $\begin{array}{c}\text { EHV-2 } \\
\text { PCR }\end{array}$ & $\begin{array}{c}\text { EHV-5 } \\
\text { PCR }\end{array}$ \\
\hline 1 & - & - & - & NT \\
\hline 2 & + & _- & - & - \\
\hline 3 & + & NT & + & - \\
\hline 4 & + & NT & + & NT \\
\hline 5 & + & NT & + & - \\
\hline 6 & - & - & + & - \\
\hline 7 & + & - & - & - \\
\hline 8 & + & - & + & - \\
\hline 9 & + & NT & + & NT \\
\hline 10 & + & NT & - & - \\
\hline 11 & + & NT & + & - \\
\hline 12 & + & NT & + & - \\
\hline 13 & + & NT & + & NT \\
\hline 14 & - & NT & + & NT \\
\hline 15 & + & NT & - & - \\
\hline 16 & + & NT & + & NT \\
\hline 17 & + & - & - & - \\
\hline 18 & + & - & + & NT \\
\hline 19 & - & - & + & NT \\
\hline 20 & - & NT & - & - \\
\hline 21 & + & NT & - & - \\
\hline 22 & + & NT & + & - \\
\hline 23 & + & - & - & - \\
\hline 24 & + & NT & - & - \\
\hline 25 & - & - & - & NT \\
\hline 26 & + & - & + & NT \\
\hline 27 & + & - & + & NT \\
\hline 28 & + & NT & - & NT \\
\hline 29 & - & - & + & - \\
\hline 30 & - & - & + & NT \\
\hline 31 & - & - & - & - \\
\hline 32 & + & NT & + & NT \\
\hline 33 & + & - & + & - \\
\hline 34 & - & - & + & - \\
\hline 35 & + & NT & - & NT \\
\hline 36 & + & - & - & NT \\
\hline 37 & - & - & - & NT \\
\hline 38 & - & - & + & NT \\
\hline 39 & & & - & NT \\
\hline 40 & & & - & NT \\
\hline 41 & & & - & NT \\
\hline 42 & & & + & NT \\
\hline 43 & & & + & NT \\
\hline
\end{tabular}

NT: not tested. 
Table III. Prevalence of DNA to EHV-2 in 81 Standard bred trotters in Sweden.

\begin{tabular}{lc}
\hline & $\begin{array}{c}\text { Number of horses harbouring } \\
\text { EHV-2 DNA in PBLs } \\
\text { tested by PCR }(\%)\end{array}$ \\
\hline Stable I & $26 / 38(68)^{\mathrm{a}}$ \\
Stable II & $24 / 43(56)$ \\
\hline
\end{tabular}

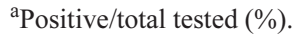

Only 5 of the 21 English adult horses (24\%) were positive to EHV-5 while all 3 foals were positive by the age of 20 to 41 weeks.

\section{DISCUSSION}

Although both EHV-2 and EHV-5 have been detected in various regions of the world, the exact prevalence and pathogenic role of these gammaherpesviruses is still not clear. In general, EHV-2 is known to be widely spread in horse populations, frequently establishing persistent and/or latent infections. In contrast, EHV-5 has so far only been isolated in a few countries, like Australia, Switzerland, Germany and New Zealand [7, 8, 11, 12] and very little is known about the pathogenic role of this virus. In Australia, EHV-5 was originally isolated from horses suffering from upper respiratory disease [8].

In order to further investigate the prevalence of EHV-2 and EHV-5 in the horse populations and to estimate the time of infection in young foals, we developed two PCR assays. The highly sensitive assays allowed the detection and discrimination of EHV-2 and EHV-5. These methods provide tools for many aspects, e.g., for the study of prevalence, pathogenesis and further biological features of the two equine gammaherpesviruses. To study the prevalence of EHV-2 and EHV-5, we tested animals from stables with a known clinical status in various European countries i.e., Sweden in North
Europe, Hungary in Central Europe as well as horses belonging to the Animal Health Trust in the United Kingdom. We used PBLs and nasal swabs available in the stocks of the institutes in the three countries. Since the samples originated from the sample banks, they were originally collected from various age groups of horses at different periods of the years. Thus, they do not represent a homogenous group of animals. However, we believe that they are still very useful for the study of prevalence of the two gammaherpes viruses in large geographic regions and in various age groups.

Although EHV-2 infection is very common, the way and location of persistence of this virus is not very well known. The PCR analysis of the collected PBL specimens revealed that as many as 56 to $68 \%$ of the horses in the two Swedish stables and 71\% of the tested English horses carried EHV-2 DNA in the PBLs. Thus our results strongly support the previous observation that EHV-2 is latent in B lymphocytes [10].

The EHV-2 infection of the Swedish horses was also confirmed by a bELISA [15] which showed that in stable I, $76 \%$ of the horses had detectable antibodies while only $28 \%$ of the tested animals in stable II were positive (note that stable I had annual respiratory problems). In the above mentioned study, the results indicate that the bELISA is a helpful tool to detect newly acquired EHV-2 infections since the figures agree with the clinical picture of the two stables and since it is well known that antibody levels obtained after a viral infection usually decrease with time. In contrast, the PCR did not reveal the real infection status of the animal but mainly showed the presence of viral DNA in the specimens.

To determine the time of infection, Hungarian foals with an annual history of combined EHV-2/R.equi respiratory disease were examined. By serial sampling of the foals we found that at the age of eight weeks, all of them were positive, i.e., the PBLs of each tested animal contained EHV-2 DNA. 
The same frequency was seen in the nasal swabs and foals excreted viruses up to the age of 23 weeks. The infection of the three English foals might occur later but by the age of 12 to 16 weeks EHV-2 DNA was detected in the PBLs. These findings support other results, where EHV-2 was detected in nasal specimens by cocultivation for as long as 2 to 6 months of age [13].

The results show that compared to EHV-2, EHV-5 has a lower prevalence in the tested populations. It was also obvious that, compared to EHV-2, the initial EHV-5 infection occurs later in life. None of the Swedish horses or foals were positive in the EHV-5 PCR while DNA was found in five of the English horses and also in the PBLs of four of the 27 Hungarian foals at the age of 13 to 23 weeks. All three foals from England were also positive to EHV-5 by the age of 20 to 41 weeks. An explanation for this fiding could be that the EHV-5 PCR was shown to be ten times less sensitive than the EHV-2 amplification test. However, since even the EHV-5 PCR can detect as few as 10 to 50 viral copies, we believe that the lower prevalence of EHV-5 is a fact in the observed equine populations. We have to consider, that the number of positive horses in Hungary and the United Kingdom and the lack of positive cases in Sweden shows a low natural prevalence, which certainly complicates the epidemiological evaluation of this virus. Further samples have to be tested in order to make a complete study on this aspect. A difference in the prevalence of EHV-2 and EHV-5 was also reported in Australia where $31 \%$ of the tested horses were positive to EHV-2 while only $16 \%$ reacted in EHV-5 PCR [17]. Other explanations on the low number of EHV-5 positive cases could be that PBLs are probably not the main reservoirs of this virus.

In conclusion, by performing various tests of virus detection on specimens collected on large geographic areas, the present study revealed interesting differences between the prevalence of EHV-2 and
EHV-5. By showing epizootiological background information, this article provides data for better understanding of the distribution and presence of these two gammaherpesviruses in various horse populations.

\section{REFERENCES}

[1] Agius C.T., Studdert M.J., Equine herpesviruses 2 and 5: Comparison with other members of the subfamily gammaherpesvirinae, Adv. Virus. Res. 44 (1994) 357-379.

[2] Alansari H., Brock K.V., Potgeiter L.N.D., Single and double polymerase chain reaction for detection of bovine viral diarrhoea virus in tissue culture and sera, J. Vet. Diagn. Invest. 5 (1993) 148-153.

[3] Belák S., Pálfi V., Bartha L., Tuboly S., Passive immunisation of foals to prevent respiratory disease caused by equine herpesvirus type 2 , Zentralbl. Veterinärmed. B 27 (1980) 826-830.

[4] Belák S., Pálfi V., Tuboly S., Bartha L., Prevention of respiratory disease of foals by immunization against equine herpesvirus type 2, Magyar Állatorvosok Lapja (Hung. Vet. J.) 36 (1981) 525-527.

[5] Belák S., Ballagi-Pordány A., Experiences on the application of the polymerase chain reaction in a diagnostic laboratory, Mol. Cell Probes 7 (1993) 241-248.

[6] Blakeslee J.R., Olsen R.G., McAllister E.S., Fassbender J., Dennis J., Evidence of respiratory tract infection induced by equine herpesvirus type 2 in the horse, Can. J. Microbiol. 21 (1975) 1940-1946.

[7] Borchers K., Frölich K., Ludwig H., Detection of equine herpesvirus types 2 and 5 (EHV-2 and EHV-5) in Przewalski's wild horses, Arch. Virol. 144 (1999) 771-780.

[8] Browning G.F., Studdert M.J., Genomic heterogeneity of equine betaherpesviruses, J. Gen. Virol. 68 (1987) 1441-1447.

[9] Browning G.F., Studdert M.J., Equine herpesvirus 2 (Equine cytomegalovirus), Vet. Bull. 58 (1988) 775-790.

[10] Drummer H.E., Reubel G.H., Studdert M.J., Equine gammaherpesvirus 2 (EHV-2) is latent in B lymphocytes, Arch. Virol. 141 (1996) 495 504.

[11] Dunowska M., Holloway S.A., Wilks C.R., Meers J., Genomic variability of equine herpesvirus-5, Arch. Virol. 145 (2000) 1359-1371.

[12] Francini, M., Akens M., Bracher V., von Fellenberg R., Characterisation of Gamma Herpesviruses in the Horse by PCR, Virology 238 (1997) 8-13. 
[13] Fu Z.F., Robinson A.J., Horner G.W., Dickinson L.G., Grimmitt J.B., Marshall R.B., Respiratory disease in foals and the epizootiology of equine herpesvirus type 2 infection, N. Z. Vet. J. 34 (1986) 152-155.

[14] Nordengrahn A., Rusvai M., Merza M., Ekstrom J., Morein B., Belák S., Equine herpesvirus type 2 (EHV-2) as a predisposing factor for Rhodococcus equi pneumonia in foals: prevention of the bifactorial disease with EHV-2 immunostimulating complexes, Vet. Microbiol. 51 (1996) 55-68.

[15] Nordengrahn A., Klingeborn B., Lindholm A., Merza M., The use of a neutralizing monoclonal antibody to detect infections of equine herpesvirus type 2 (EHV-2), J. Vet. Diagn. Invest. 13 (2001) 389-393.

[16] Pálfi V., Belák S., Molnár T., Isolation of equine herpesvirus type 2 from foals showing respiratory symptoms, Zentralbl. Veterinärmed. B 25 (1978) 165-167.
[17] Reubel G.H., Crabb B.S., Studdert M.J., Diagnosis of gammaherpesvirus 2 and 5 infections by polymerase chain reaction, Arch. Virol. 140 (1995) 1049-1060.

[18] Sambrook J., Fritsch E.F., Maniatis T., Molecular cloning. A laboratory manual, 2nd ed., Cold Spring Harbor, New York, 1989.

[19] Telford E.A.R., Studdert M.J., Agius C.T., Watson M.S., Aird H.C., Davison A.J., Equine herpesviruses 2 and 5 are g-herpesviruses, Virology 195 (1993) 492-499.

[20] Telford E.A.R., Watson M.S., Aird H.C., Perry J., Davison A.J., The DNA sequence of equine herpesvirus 2, J. Mol. Biol. 249(1995) 520-528.

[21] Thein P., Böhm D., Ätiologie und Klinik einer virusbedingten Keratokonjunktivitis beim Fohlen, Zentralbl. Veterinärmed. B 23 (1976) 507-519.

[22] Thein P., Härtl G., Untersuchungen zur Virusätiologie respiratorischer Erkrankungen des Pferdes, in: Der Praktische Tierärzt Collegium Veterinarium, 1976, pp. 24-29. 